\title{
PENDIDIKAN KARAKTER MENURUT KH. WAHID HASYIM
}

\author{
Rangga Sa'adillah S. A. P. \\ (Sekolah Tinggi Agama Islam Taswirul Afkar Surabaya)
}

\begin{abstract}
Abstrak:
Studi library research ini berusaha menjawab dua pertanyaan. Pertama bagaimana pemikiran KH. Wahid Hasyim tentang pendidikan karakter? Kedua bagaimana relevansi konsep pendidikan karakter KH. Wahid Hasyim dengan kondisi pendidikan di Indonesia saat ini? Melalui analisis induktif dihasilkan dua temuan. Pertama, terdapat delapan nilai-nilai karakter yang berusaha ditanamkan oleh KH. Wahid Hasyim. Delapan nilai tersebut adalah religius, toleransi, madiri, demokratis, semangat kebangsaan, cinta tanah air, bersahabat atau komunikatif, dan gemar membaca. Temuan kedua pada penelitian ini, bahwa pemikiran pendidikan karakter KH. Wahid Hasyim sejalan dengan tujuan pendidikan karakter. Dia berikhtiar membangun kehidupan kebangsaan yang multikultural; membangun peradaban bangsa yang cerdas, berbudaya luhur, dan mampu berkontribusi terhadap pengembangan kehidupan umat manusia, mengembangkan potensi dasar agar berhati baik, berpikiran baik, dan berperilaku baik serta keteladanan baik; membangun sikap warganegara yang mencintai kedamaian, kreatif, mandiri, dan mampu hidup berdampingan dengan bangsa lain dalam suatu harmoni.
\end{abstract}

Kata Kunci : Pendidikan, Karakter, KH. Wahid Hasyim. 


\begin{abstract}
:
This library research examined two research questions. They are what thoughts of $\mathrm{KH}$. Wahid Hasyim about the character education are and how the concept of character education by $\mathrm{KH}$. Wahid Hasyim is relevant to the current condition of education in Indonesia. This study reveals two findings through an inductive analysis. The chief finding of this study is that there are eight characteristic values taught by KH.Wahid Hasyim including religious, tolerant, independent, democratic, patriotic, nasionalist, communicative, and keen on reading. Second, this study disclosed that the thought of character education by $\mathrm{KH}$. Wahid Hasyim is in line with the goal of character education. He strove to build a multicultural national life, educate an intelligent civilization, build a noble character, encourage people to contribute to the development of human life, and develop the potential of having kind hearts, positive thoughts and good behavior as well as exemplary models. He also sought to generate enthusiasm of citizens to keep the peace, creativity, independence, and to be able to coexist with other nations in a harmony.
\end{abstract}

Keywords : Character, Education, KH. Wahid Hasyim.

\title{
A. Pendahuluan
}

Hingga kini pendidikan terus-menerus dibangun dan dikembangkan agar menghasilkan generasi yang diharapkan. Dalam rangka menghasilkan peserta didik yang diharapkan dan unggul, proses pendidikan juga senantiasa dievaluasi dan diperbaiki. Salah satu upaya perbaikan kualitas pendidikan adalah gagasan pendidikan karakter. Gagasan ini muncul karena proses pendidikan selama ini dinilai belum sepenuhnya berhasil dalam membangun manusia Indonesia yang berkarakter. Bahkan, ada juga yang menyebut bahwa pendidikan Indonesia telah gagal dalam membangun karakter. Penilaian ini didasarkan pada lulusan sekolah dan sarjana yang cerdas secara intelektual, namun tidak bermental tangguh dan berperilaku sesuai dengan tujuan mulia pendidikan. ${ }^{1}$

Lebih-lebih saat ini banyak insan-insan yang terdidik di negeri ini memiliki perilaku yang tidak sesuai dengan tujuan pendidikan. Misalnya tindak korupsi yang ternyata dilakukan oleh pejabat yang notabenenya orang-orang berpendidikan. Belum lagi tindak kekerasan yang akhir-akhir ini marak terjadi di

1 Tujuan mulia Pendidikan Nasional adalah mengembangkan kemampuan dan membentuk watak serta peradaban bangsa yang bermartabat dalam rangka mencerdaskan bangsa. Lihat Undang-Undang Republik Indonesia Nomor 20 Tahun 2003 Tentang Sistem Pendidikan Nasional Bab II Dasar, Fungsi, dan Tujuan Pasal 3. 
Rangga Sa'adillah S. A. P.

negeri ini seperti anarkis, bahkan pembunuhan, tawuran antar pelajar, kasus narkoba, dan tindak asusila. Parahnya bila kenyataan demikian yang terjadi selalu yang disalahkan adalah pendidikan agama. Belum lagi baru-baru ini sering terjadi tindakan terorisme dan kekerasan atas nama agama.

Lalu apakah pendidikan itu hanya merupakan mesin yang menghasilkan manusia cerdas secara intelektual?. Tidak, pendidikan merupakan usaha sadar dan terencana untuk mewujudkan suasana belajar dan proses pembelajaran agar peserta didik ${ }^{2}$ secara aktif mengembangkan potensi diri untuk memiliki kekuatan spiritual keagamaan, pengendalian diri, kepribadian, kecerdasan, akhlak mulia, serta keterampilan yang diperlukan dirinya, masyarakat bangsa dan negara. ${ }^{3}$ Pendidikan merupakan bimbingan atau pimpinan secara sadar oleh si pendidik terhadap perkembangan jasmani dan rohani si terdidik menuju terbentuknya kepribadian yang utama. ${ }^{4}$

Untuk membentuk manusia yang mulia dan bangsa yang bermartabat salah satu upaya yang dilakukan adalah melalui pendidikan karakter. Upaya ini menjadi fondasi utama dalam mensukseskan Indonesia di masa mendatang. ${ }^{5}$ Membentuk karakter bangsa yang beradab dan berbudaya.

Bangsa ini memerlukan pendidikan karakter, ${ }^{6}$ yakni karakter yang bernafaskan nilai-nilai agama.7 Atau dengan kata lain (agama Islam) adalah Pendidikan Islam Berbasis Karakter. Untuk itu penelitian ini berusaha menggali

2 Peserta didik adalah anggota masyarakat yang berusaha mengembangkan potensi diri melalui proses pembelajaran yang tersedia pada jalur, jenjang, dan jenis pendidikan tertentu. Lihat Undang-Undang Republik Indonesia Nomor 20 Tahun 2003 Tentang Sistem Pendidikan Nasional pada Bab I Ketentuan Umum Pasal 1. Selebihnya istilah-istilah praktis Pendidikan seperti jalur pendidikan, jenjang pendidikan, jenis pendidikan juga telah juga telah diputuskan dalam UU SISDIKNAS BAB I Ketentuan Umum Pasal 1.

3 Undang-Undang Republik Indonesia Nomor 20 Tahun 2003 Tentang Sistem Pendidikan Nasional Bab I Ketentuan Umum Pasal 1 ayat (1).

${ }^{4}$ Ahmad D. Marimba, Pengantar ..., 19.

${ }^{5}$ Akhmad Muhaimin Azzet, Urgensi Pendidikan Karakter di Indonesia, (Yogyakarta: Ar-Ruzz Media, 2011), 11-12.

${ }^{6}$ Sebenarnya yang diusung untuk dijadikan dasar dalam pendidikan karakter adalah nilai-nilai agama yang bersifat universal. Nilai-nilai universal agama yang dijadikan dasar dalam pendidikan karakter sangat penting karena keyakinan seseorang terhadap kebenaran nilai yang berasal dari agamanya bisa menjadi motivasi yang kuat untuk membangun karakter. Dalam hal penanaman nilai bangsa Indonesia memang sangat memerlukan model pendidikan semacam ini. Sebab pendidikan bukan hanya sebagai wahana untuk mendidik anak didik menjadi cerdas semata, melainkan juga berkarakter. Lihat Akhmad Muhaimin Azzet, Urgensi Pendidikan Karakter di Indonesia, (Yogyakarta: Ar-Ruzz Media, 2011), 18.

7 Pendidikan agama adalah pendidikan yang memberikan pengetahuan dan membentuk sikap, kepribadian, dan keterampilan peserta didik dalam mengamalkan ajaran agamanya. Lihat Peraturan Pemerintah Republik Indonesia Nomor 55 Tahun 2007 Tentang Pendidikan Agama dan Keagamaan Bab I Ketentuan Umum Pasal 1 Ayat (1).

Jurnal Pendidikan Agama Islam

Volume 3 Nomor 2 November 2015

ISSN: 2089-1946

Hal. 278 - 303 
salah satu tokoh yang getol menanamkan nilai-nilai agama dalam pendidikan yakni KH. Wahid Hasyim. Dia lahir di Jombang pada hari Jumat Legi 5 Rabiul Awal 1333 H/ 1 Juni 1914 M. Putra pertama Hadratus Syeikh K.H. M. Hasyim Asy'ari, pendiri jam'iyyah $\mathrm{NU}^{8}$ yang mempunyai silsilah sampai pada Sultan Brawijaya VI baik dari jalur ibu maupun Ayahnya. ${ }^{9}$ Nama yang pertama diberikan ketika ia lahir adalah Muhammad Asy'ari, meniru nama kakeknya. Tetapi karena ia sering sakit, maka namanya itu diganti dengan Abdul Wahid, nama salah seorang kakek moyangnya. Selama masa kecilnya ia dipanggil oleh ibunya dengan nama Mudin, sedang santri ayahnya memanggil dia dengan panggilan Gus Wahid. ${ }^{10}$

K.H. Wahid Hasyim tidak pernah mengenyam pendidikan di bangku sekolah pemerintahan Hindia Belanda. Dia lebih banyak belajar secara autodidak. Selama belajar di Pondok Pesantren dan Madrasah, dia banyak mempelajari sendiri kitab-kitab dan buku berbahasa Arab. Dia mendalami syair-syair berbahasa Arab hingga hafal diluar kepala, selain itu juga menguasai maknanya dengan baik. ${ }^{11}$ Masa mudanya banyak dihiasi dengan pengembaraan ilmu di pesantren, di antaranya: Pesantren Tebu Ireng milik ayahnya sendiri, Pesantren Siwalan Panji, dan Lirboyo. Seperti halnya tokoh-tokoh besar pada masanya, tujuan dari pengembaraan ilmu tersebut tak lain adalah untuk mencari barokah dari sang guru. Karena banyak catatan dari aktivitas pendidikan KH. Wahid Hasyim sering berpindah tempat. ${ }^{12}$

Kiprah KH. Wahid Hasyim di dunia pendidikan banyak dilihat ketika dia mendirikan madrasah modern yang dinamakan Madrasah Nizamiyah pada tahun 1935. Madrasah ini sebagai pelopor lembaga pendidikan Islam yang mampu mensinergikan antara pendidikan umum dengan pendidikan Islam.13 Kemudian puncak kariernya K. H. Wahid Hasyim menjadi Menteri Agama tiga periode, yaitu

8 Aboebakar, Sedjarah K.H.A. Wahid Hasjim dan Karangan Tersiar, (Jakarta: Panitya Buku Peringatan Alm. K.H.A. Wahid Hasjim, 1957), 141. Bandingkan dengan Soeleiman Fadeli, Mohammad Subhan, Buku I Antologi NU Sejarah-Istilah-Amaliah-Uswah, (Surabaya: Khalista, cet. I 2007), 303.

9 Silsilah dari jalur ayah K.H. Abdul Wahid Hasyim bersambung hingga Joko Tingkir, tokoh yang dikenal dengan nama Sultan Sutawijaya yang berasal dari Kerajaan Islam Demak. Sedangkan, dari pihak ibu, silsilah bersambung hingga Ki Ageng Tarub, bila ditarik lebih jauh, kedua silsilah itu bertemu pada satu titik, yaitu Sultan Brawijaya VI, yang menjadi salah satu Raja Kerajaan Mataram. Sultan Brawijaya VI dikenal dengan sebutan Lembu Peteng. Untuk lebih lengkapnya lihat Aboebakar, Sedjarah ..., 139-140.

10 Achmad Zaini, K.H. Abdul Wahid Hasyim Pembaru Pendidikan Islam, (Jombang: Pesantren Tebuireng, 2011), 6. Bandingkan dengan Rijal Mumazziq Z., Relasi Agama dan Negara Dalam Perspektif K.H. A. Wahid Hasyim dan Relevansinya Dengan Kondisi Sekarang, (Skripsi), (Surabaya: Jurusan Siyasah Jinayah Fakultas Syariah IAIN Sunan Ampel Surabaya, 2009), 44.

11 Mohammad Rifai, Wahid..., 23.

12 Ibid., 23.

${ }^{13}$ Achmad Zaini, K.H. Abdul ..., 41-42. 
Rangga Sa'adillah S. A. P.

dalam Kabinet Hatta (20 Desember 1949 - 6 Desember 1950), Kabinet Natsir (6 September 1950 - 27 April 1951), dan Kabinet Sukiman (27 April 1951 - 3 April 1952), dia mengeluarkan tiga buah keputusan yang pada tahun-tahun selanjutnya mempengaruhi sistem Pendidikan di Indonesia.14 Dipuncak karier tersebut gagasan-gagasannya banyak terabadikan dalam tulisan-tulisannya sebagai Menteri Agama. Dari berbagai macam tema tersebut penelitian ini lebih berkonsentrasi pada tema pendidikan dan keagamaan. Berikut karya tulis K. H. Wahid Hasyim dibidang pendidikan dan keagamaan:

a. Abdullah Ubaid Sebagai Pendidik dalam Suluh NU, Agustus 1941, tahun ke-1 No. 5.15

b. Kemajuan Bahasa, Berarti Kemajuan Bangsa dalam Suara Ansor, Rajab 1360 Th. IV No. 3., ditulis dengan nama Banu Asy'ari.16

c. Pendidikan Ketuhanan dalam Mimbar Agama Tahun 1 No. 5 - 6, 17 Nopember - 17 Desember 1950.17

d. Perguruan Tinggi Islam Pidato menyambut berdirinya Universitas Islam Sumatera Utara di Medan 21 Juni 1952.18

e. Perguruan Tinggi Agama Islam Negeri Pidato pada pembukaan dan penyerahan PTAIN di Yogyakarta 26 September 1951.19

f. Pentingnya Terjemah Hadits Pada Masa Pembangunan termuat sebagai kata sambutan dalam kitab Terjemah Hadits Bukhari (1953) diterbitkan Fa. Widjaja: Jakarta. ${ }^{20}$

g. Tuntutan Berfikir kata pendahuluan agenda Kementrian Agama 1951 1952.21

h. Nabi Muhammad dan Persaudaraan Manusia karya ini merupakan pidatonya pada acara pembukaan Perayaan Maulid Nabi Muhammad yang diadakan di Istana Negara, Jakarta, pada 2 Januari 1950, dan merupakan perayaan Maulid pertama sesudah penyerahan kedaulatan Republik Indonesia. ${ }^{22}$

14 Mohammad Rifai, Wahid..., 39.

15 Aboebakar, Sedjarah K.H.A. Wahid Hasjim dan Karangan Tersiar, (Jakarta: Panitya Buku Peringatan Alm. K.H.A. Wahid Hasjim, 1957), 791.

16 Aboebakar, Sedjarah...,797. Badingkan dengan Sanusi, K. H. A. Wahid Hasyim Mengapa Memilih NU? Konsepsi Tentang Agama, Pendidikan dan Politik, (Jakarta: PT Inti Sarana Aksara, 1985), 65

17 Ibid., 74.

18 Ibid., 81.

19 Ibid., 84.

20 Ibid., 70.

21 Ibid., 74.

22 Ibid., 19.

Jurnal Pendidikan Agama Islam

Volume 3 Nomor 2 November 2015

ISSN: 2089-1946

Hal. 280 - 303 
i. Kebangkitan Dunia Islam karya ini merupakan tulisannya di media Mimbar Agama edisi No. 3 - 4, Maret - April 1951.23

j. Beragamalah Dengan Sungguh-sungguh dan Ingatlah Kebesaran Tuhan. Karya ini merupakan semacam pidato untuk perayaan Hari Raya Idul Fitri yang pada saat itu, Indonesia masih berbentuk Serikat, atau RIS (Republik Indonesia Serikat). ${ }^{24}$

\section{B. Pendidikan Karakter}

Pendidikan karakter adalah sebuah sistem yang menanamkan nilai-nilai karakter pada peserta didik, mengandung komponen pengetahuan, kesadaran individu, tekat, serta adanya kemauan dan tindakan untuk melaksanakan nilainilai, baik terhadap Tuhan Yang Maha Esa, diri sendiri, sesama manusia, lingkungan maupun bangsa, sehingga akan terwujud insan kamil.25

Makna karakter itu sendiri sebenarnya berasal dari bahasa Yunani yang berarti to mark atau menandai dan memfokuskan pada aplikasi nilai kebaikan dalam bentuk tindakan atau tingkah laku, sehingga orang yang tidak jujur, kejam, rakus, dan berperilaku jelek dikatakan sebagai orang berkarakter jelek. Sebaliknya, orang yang berperilaku sesuai dengan kaidah moral ${ }^{26}$ dinamakan berkarakter mulia.

23 Aboebakar, Sedjarah...,681. Oleh Rifai karya ini dimasukkan dalam ketegori pemikiran keagamaan K. H. Abdul Wahid Hasyim lihat Rifai, Wahid..., 43. Namun oleh Sanusi karya ini masuk pada kategori pemikiran politik K. H. Abdul Wahid Hasyim lihat Sanusi, K. H. A. Wahid..., 156.

${ }^{24}$ Aboebakar, Sedjarah...,687. Bandingkan dengan Sanusi K. H. A. Wahid..., 22.

25 Nurla Isna Aunillah, Panduan Menerapkan Pendidikan Karakter di Sekolah, (Jogjakarta: Laksana, 2011), 19. Bandingkan dengan Akhmad Sudrajat, "Tentang Pendidikan Karakter", dalam http://akhmadsudrajat.wordpress.com/2010/08/20/pendidikan-karakter-di-smp, diakses pada tanggal 10 Desember 2011, pukul 09.45 WIB.

26 Perkataan moral berasal dari bahasa latin mores kata jama' dari mos yang berarti adat kebiasaan. Dalam bahasa Indonesia moral diterjemahkan dengan arti susila. Lebih lanjut yang dimaksud dengan moral ialah sesuai dengan ide-ide yang umum diterima tentang kaidah manusia mana yang baik dan wajar. Lihat Abdul Majid, Dian Andayani, Pendidikan Karakter Perspektif Islam, (Bandung: PT Remaja Rosdakarya, 2011), 8. Menurut T. Ramli (2003), pendidikan karakter memiliki esensi dan makna yang sama dengan pendidikan moral dan pendidikan akhlak. Tujuannya adalah membentuk pribadi anak, supaya menjadi manusia yang baik, warga masyarakat, dan warga negara yang baik. Adapun kriteria manusia yang baik, warga masyarakat yang baik, dan warga negara yang baik bagi suatu masyarakat atau bangsa, secara umum adalah nilai-nilai sosial tertentu, yang banyak dipengaruhi oleh budaya masyarakat dan bangsanya. Oleh karena itu, hakikat dari pendidikan karakter dalam konteks pendidikan di Indonesia adalah pedidikan nilai, yakni pendidikan nilai-nilai luhur yang bersumber dari budaya bangsa Indonesia sendiri, dalam rangka membina kepribadian generasi muda. Akhmad Sudrajat, Konsep Pendidikan Karakter, 
Rangga Sa'adillah S. A. P.

Seseorang dianggap memiliki karakter mulia apabila mempunyai pengetahuan yang mendalam tentang potensi dirinya serta mampu mewujudkan potensi itu dalam sikap dan tingkahlak. Ciri seorang yang mampu memanfaatkan potensi dirinya adalah terpupuknya sikap-sikap terpuji, seperti penuh reflektif, percaya diri, rasional, logis, kritis, analitis, kreatif-inovatif, mandiri, berhati-hati, rela berkorban, berani, dapat dipercaya, jujur, menepati janji, adil, rendah hati, malu berbuat salah, pemaaf, berhati lembut, setia, bekerja keras, tekun, ulet, gigih, teliti, berinisiatif, berpikir positif, disiplin, antisipatif, visioner, bersahaja, bersemangat, dinamis, hemat, efisien, menghargai waktu, penuh pengabdian, dedikatif, mampu mengendalikan diri, produktif, ramah, cinta keindahan, sportif, tabah, terbuka, dan tertib. ${ }^{27}$

Pendidikan karakter bertujuan mengembangkan nilai-nilai yang membentuk karakter bangsa yaitu Pancasila, meliputi: 1) mengembangkan potensi peserta didik agar menjadi manusia berhati baik, berpikiran baik, dan berperilaku baik; 2) membangun bangsa yang berkarakter Pancasila; 3) mengembangkan potensi warganegara agar memiliki sikap percaya diri, bangga pada bangsa dan negaranya serta mencintai umat manusia. ${ }^{28}$

Pendidikan karakter berfungsi 1) membangun kehidupan kebangsaan yang multikultural: 2) membangun peradaban bangsa yang cerdas, berbudaya luhur, dan mempu berkontribusi terhadap pengembangan kehidupan ummat manusia, mengembangkan potensi dasar agar berhati baik, berpikiran baik, dan berperilaku baik serta keteladanan baik; 3) membangun sikap warganegara yang mencintai damai, kreatif, mandiri, dan mampu hidup berdampingan dengan bangsa lain dalam suatu harmoni. ${ }^{29}$

Menurut Zubaedi, pendidikan karakter di Indonesia didasarkan pada sembilan pilar karakter dasar. Karakter dasar tersebut menjadi tujuan pendidikan karakter, diantaranya adalah: 1) cinta kepada Allah dan semesta beserta isinya; 2) tanggungjawab, disiplin, dan mandiri; 3) jujur; 4) hormat dan santun; 5) kasih

http://akhmadsudrajat.wordpress.com /2010/09/15/konsep-pendidikan-karakter/ diakses pada tanggal 10 Desember 2011, pukul 16.39 WIB.

27 Ibid.

28 Tim Penyusun, Panduan Pelaksanaan Pendidikan karakter, (Jakarta: Kementerian Pendidikan Nasional, 2011), 3. Akhmad Sudrajat juga menjelaskan tujuan Pendidikan karakter adalah untuk meningkatkan mutu penyelenggaraan dan hasil pendidikan di sekolah yang mengarah pada pencapaian pembentukan karakter dan akhlak mulia peserta didik secara utuh, terpadu, dan seimbang, sesuai standar kompetensi lulusan. Melalui pendidikan karakter diharapkan peserta didik mampu secara mandiri meningkatkan dan menggunakan pengetahuannya, mengkaji dan menginternalisasi serta mempersonalisasi nilai-nilai karakter dan akhlak mulia sehingga terwujud dalam perilaku sehari-hari. Akhmad Sudrajat, Tentang..., diakses pada tanggal 10 Desember 2011, pukul 09.45 WIB.

${ }^{29}$ Tim Penyusun, Panduan ..., 3.

Jurnal Pendidikan Agama Islam

Volume 3 Nomor 2 November 2015

ISSN: 2089-1946

Hal. 282 - 303 
sayang, peduli dan kerjasama; 6) percaya diri, kreatif, kerja keras, dan pantang menyerah; 7) keadilan dan kepemimpinan; 8) baik dan rendah hati; 9) cinta damai dan persatuan. ${ }^{30}$

Pendidikan karakter di Indonesia selain mengambil dari nilai-nilai universal agama ${ }^{31}$ pada dasarnya merupakan pengembangan dari nilai-nilai yang berasal dari pandangan hidup atau ideologi bangsa, budaya, dan nilai-nilai dalam tujuan pendidikan nasional. Adapun nilai-nilai tersebut meliputi: nilai keagamaan, nilai pancasilan, nilai budaya, dan nilai tujuan pendidikan nasional. Penjelasan nilai-nilai tersebut dijabarkan pada paragraf di bawah ini:

Pertama, agama. ${ }^{32}$ Masyarakat Indonesia merupakan masyarakat beragama. Oleh karena itu kehidupan individu, masyarakat, dan bangsa, selalu didasari pada ajaran agama dan kepercayaannya. Maka dari itu nilai-nilai pendidikan karakter harus didasarkan pada nilai keagamaan.

Kedua, Pancasila. Negara Kesatuan Republik Indonesia ditegakkan atas prinsip-pinsip kehidupan kebangsaan dan kenegaraan yang disebut Pancasila. Pendidikan karakter bertujuan mempersiapkan peserta didik menjadi warga negara yang lebih baik maka sewajarnya nilai ini diambil sebagai nilai pilar pendidikan karakter.

Ketiga, budaya. Nilai budaya ini dijadikan dasar dalam pemberian makna terhadap suatu konsep dan arti dalam komunikasi antar anggota masyarakat. Maka demikian penting nilai budaya ini menjadi sumber bagi pendidikan karakter.

Keempat, tujuan pendidikan nasional. Undang-Undang Republik Indonesia Nomor 20 Tahun 2003 Tentang Sistem Pendidikan Nasional atau yang lebih akrab disebut sebagai UU SISDIKNAS mencantumkan tujuannya dalam pasal 3. "Pendidikan Nasional berfungsi mengembangkan dan membentuk watak serta peradaban bangsa dan yang bermartabat dalam rangka mencerdaskan kehidupan bangsa, bertujuan untuk berkembangnya potensi peserta didik agar menjadi manusia yang beriman dan bertaqwa kepada Tuhan Yang Maha Esa, berkahlak mulia, sehat, berilmu, cakap, kreatif, mandiri, dan menjadi warga negara yang demokratis dan bertanggungjawab. Oleh karena itu tujuan pendidikan nasional adalah sumber yang paling operasional dalam pengembangan pendidikan karakter.

Berdasarkan keempat sumber nilai diatas, teridentifikasi sejumlah nilai untuk pendidikan karakter, sebagaimana tersaji pada tabel 1 di bawah ini:

\footnotetext{
${ }^{30}$ Pendapat ini juga ada dalam Abdul Majid dan Dian Andayani, Pendidikan ..., 43.

${ }^{31}$ Lihat Akhmad Muhaimin Azzet, Urgensi..., 18.

32Pijakan utama yang harus dijadikan sebagai landasan dalam menerapkan pendidikan karakter adalah moral universal yang dapat digali dari agama. Lihat Nurla Isna Aunillah, Panduan..., 23.
} 
Tabel 1.

Nilai dan Deskripsi Nilai Pendidikan Karakter ${ }^{33}$

\begin{tabular}{|c|c|c|}
\hline No. & Nilai & Deskripsi \\
\hline 1. & Religius & $\begin{array}{l}\text { Sikap dan perilaku yang patuh dalam } \\
\text { melaksanakan ajaran agama yang dianutnya, } \\
\text { toleran terhadap pelaksanaan ibadah agama } \\
\text { lain, dan hidup rukun dengan pemeluk agama } \\
\text { lain. }\end{array}$ \\
\hline 2. & Jujur & $\begin{array}{l}\text { Perilaku yang didasarkan pada upaya } \\
\text { menjadikan dirinya sebagai orang yang selalu } \\
\text { dapat dipercayai dalam perkataan, tindakan, } \\
\text { dan pekerjaan. }\end{array}$ \\
\hline 3. & Toleransi & $\begin{array}{l}\text { Sikap dan tindakan yang menghargai perbedaan } \\
\text { agama, suku, etnis, pendapat, sikap, dan } \\
\text { tindakan orang lain yang berbeda dari dirinya. }\end{array}$ \\
\hline 4. & Disiplin & $\begin{array}{l}\text { Tindakan yang menujukkan perilaku tertib dan } \\
\text { patuh pada berbagai ketentuan dan peraturan. }\end{array}$ \\
\hline 5. & Kerja keras & $\begin{array}{l}\text { Perilaku yang menujukkan upaya sungguh- } \\
\text { sungguh dalam mengatasi berbagai hambatan } \\
\text { belajar dan tugas, serta menyelesaikan tugas } \\
\text { dengan sebaik-baiknya. }\end{array}$ \\
\hline 6. & Kreatif & $\begin{array}{l}\text { Berfikir dan melakukan sesuatu untuk } \\
\text { menghasilkan cara atau hasil baru dari sesuatu } \\
\text { yang telah dimiliki. }\end{array}$ \\
\hline 7. & Mandiri & $\begin{array}{l}\text { Sikap dan perilaku yang tidak mudah tergantung } \\
\text { pada orang lain dalam menyelesaikan tugas- } \\
\text { tugas. }\end{array}$ \\
\hline 8. & Demokratis & $\begin{array}{l}\text { Cara berpikir, bersikap, dan bertindak yang } \\
\text { menilai sama hak dan kewajiban dirinya dan } \\
\text { orang lain. }\end{array}$ \\
\hline 9. & Rasa ingin tahu & $\begin{array}{l}\text { Sikap dan tindakan yang selalu berupaya untuk } \\
\text { mengetahui lebih mendalam dan meluas dari } \\
\text { sesuatu yang dipelajarinya, dilihat, dan } \\
\text { didengar. }\end{array}$ \\
\hline
\end{tabular}

33 Zubaedi, Desain..., 74., Tim, Panduan..., 4., Deskripsi nilai diatas sudah dirumuskan dalam Desain Induk Pendidikan Karakter (DIPK) yang dikeluarkan oleh Kementrian Pendidikan Nasional. Lihat Hasran Punggeti, Pengaruh Pendidikan Karakter Dalam Menanggulangi Deliquency Siswa Kelas VIII di SMP al-Islah Surabaya, (Skripsi), (Surabaya: Jurusan Pendidikan Agama Islam Fakultas Tarbiyah IAIN Sunan Ampel, 2011), 20. 


\begin{tabular}{|c|c|c|}
\hline 10. & Semangat kebangsaan & $\begin{array}{l}\text { Cara berfikir, bertindak, dan berwawasan yang } \\
\text { menempatkan kepentingan bangsa dan negara } \\
\text { diatas kepentingan diri dan kelompoknya. }\end{array}$ \\
\hline 11. & Cinta tanah air & $\begin{array}{l}\text { Cara berpikir, bersikap, dan berbuat yang } \\
\text { menujukkan kesetiaan, kepedulian, dan } \\
\text { penghargaan yang tinggi terhadap bangsa, } \\
\text { lingkungan fisik, sosial, budaya, ekonomi, dan } \\
\text { politik bangsa. }\end{array}$ \\
\hline 12. & Menghargai prestasi & $\begin{array}{l}\text { Sikap dan tindakan yang mendorong dirinya } \\
\text { untuk menghasilkan sesuatu yang berguna bagi } \\
\text { masyarakat, dan mengakui, serta menghormati } \\
\text { keberhasilan orang lain. }\end{array}$ \\
\hline 13. & Bersahabat/komuniktif & $\begin{array}{l}\text { Tindakan yang memperlihatkan rasa senang } \\
\text { berbicara, bergaul, dan bekerjasama dengan } \\
\text { orang lain. }\end{array}$ \\
\hline 14. & Cinta damai & $\begin{array}{l}\text { Sikap, perkataan, dan tindakan yang } \\
\text { menyebabkan orang lain merasa senang dan } \\
\text { aman atas kehadiran dirinya. }\end{array}$ \\
\hline 15. & Gemar membaca & $\begin{array}{l}\text { Kebiasaan menyediakan waktu untuk membaca } \\
\text { berbagai yang memberikan kebaikan bagi } \\
\text { dirinya. }\end{array}$ \\
\hline 16. & Peduli lingkungan & $\begin{array}{l}\text { Sikap dan tindakan yang selalu berupaya } \\
\text { mencegah kerusakan pada lingkungan di } \\
\text { sekitarnya, dan mengembangkan upaya-upaya } \\
\text { untuk memperbaiki kerusakan alam yan sudah } \\
\text { terjadi. }\end{array}$ \\
\hline 17. & Pedulli sosial & $\begin{array}{l}\text { Sikap dan tindakan yang selalu ingin memberi } \\
\text { bantuan pada orang lain dan masyarakat yang } \\
\text { membutuhkan. }\end{array}$ \\
\hline 18. & Tanggung jawab & $\begin{array}{l}\text { Sikap dan perilaku seseorang untuk } \\
\text { melaksanakan tugas dan kewajibannya, yang } \\
\text { seharusnya dilakukan terhadap diri sendiri, } \\
\text { masyarakat, lingkungan (alam, sosial, dan } \\
\text { budaya), negara, dan Tuhan Yang Maha Esa. }\end{array}$ \\
\hline
\end{tabular}


Rangga Sa'adillah S. A. P.

\section{HASIL DAN PEMBAHASAN \\ Pemikiran Pendidikan Karakter KH. Wahid Hasyim}

Terdapat delapan nilai karakter yang terintegrasi dalam pemikiran pendidikan K.H. Wahid Hasyim. Delapan nilai karakter tersebut dijelaskan dalam uraian berikut:

\section{Religius}

Sebagai seorang ulama' segala ucapan tindakan ataupun tingkahlaku KH. Wahid Hasyim harus berdasarkan ajaran dan pedoman agama (Islam). Nilai karakter religius tercermin pada pidato pembukaan perayaan Maulid Nabi Muhammad S.A.W. di Istana Negara pada 2 Januari 1950 yang berjudul "Nabi Muhammad dan Persaudaraan Manusia".

Bagi KH. Wahid Hasyim agama dihadirkan ke muka bumi untuk kebaikan seluruh penghuninya karena di dalam agama diajarkan bagaimana menolong satu sama lain, bagaimana tidak boleh bersikap sombong terhadap orang miskin. Karena harta hanyalah titipan. Lebih lanjut dia berpendapat, bahwa konteks kelahiran Nabi Muhammad sebenarnya bukan hanya untuk umat Islam saja, melainkan untuk seluruh umat manusia. Oleh karena itu, ajaran Islam mengajarkan sikap tolong menolong dan menjauhkan sikap benci dan menganjurkan untuk saling memaafkan satu sama lain. Nabi Muhammad lahir di tengah kondisi masyarakat jahiliyah yang selalu mengagung-agungkan hidup materi, bergaya hidup hedonis, merendahkan derajat kaum lemah, orang miskin, janda, hamba sahaya, dan anak yatim.

Kehadiran Nabi Muhammad menempatkan bagaimana inti ajaran sebuah agama, terutama agama Islam, pada persaudaraan manusia. Dia mencontohkan Nabi Muhammad dapat melindungi dan menghargai pemeluk agama dan suku lain dalam Piagam Madinah. ${ }^{34}$ Dalam pemikiran religius, KH. Wahid Hasyim mengajarkan bagaimana umat Islam harus memperkuat rasa persaudaraan satu sama lain.

Sebagai seorang pendidik, KH. Wahid Hasyim merupakan pribadi yang patut dijadikan tauladan, KH. Saifuddin Zuhri ${ }^{35}$ menuliskan dalam suratnya tertanggal 13 April 1957 tentang pribadi KH. Abdul Wahid Hasyim:

“... Kepada murid-murid dan pembantu-pembantunya. Almarhum (KH. Abdul Wahid Hasyim. Pen) senantiasa mendidik dengan sungguh-sungguh, baik

\footnotetext{
${ }^{34}$ Mohammad Rifai, Wahid Hasyim..., 94-95.

35 Syaifuddin Zuhri merupakan anak asuh dari KH. Abdul Wahid Hasyim. Sebagai seorang pendidik KH. Abdul Wahid Hasyim dapat mengkader Syaifuddin Zuhri sampai menduduki jabatan Menteri Agama RI tahun 1962-1967. Lebih lengkapnya kisah perjuangan hidup Syaifuddin Zuhri bersama KH. Abdul Wahid Hasyim lihat KH. Syaifuddin Zuhri, Guruku Orang-orang Dari Pesantren, (Yogyakarta: Pustaka Sastra LkiS, 2001).
}

Jurnal Pendidikan Agama Islam

Volume 3 Nomor 2 November 2015

ISSN: $2089-1946$

Hal. 286 - 303 
dengan nasehat-nasehat maupun dengan contoh perbuatan. Diberinya kesempatan bagi murid-muridnya untuk menyelesaikan sesuatu, sambil diberinya petunjuk-petunjuk seperlunya, lalu dituntunnya murid yang sedang diasuh itu. Kejadian semacam ini tidak hanya untuk sekali dua, akan tetapi untuk seterusnya, untuk berbilang bulan dan tahun. ${ }^{36}$

Nampak dari pernyataan dan kesaksian KH. Syaifuddin Zuhri bahwa sosok KH. Wahid Hasyim merupakan pendidik yang dapat memberikan tauladan yang baik, dan memberikan perhatian besar terhadap anak asuh. Sebagai seorang pendidik yang religius KH. Wahid Hasyim juga mencontohkan bagaimana dia hidup dalam kesederhanaan meskipun dia seorang Menteri. Hal ini dituturkan oleh anaknya Umar Wahid:

"... Selama tujuh tahun terakhir hidupnya Beliau berpuasa setiap hari kecuali pada hari-hari yang diharamkan berpuasa. Tetapi hal itu tidak mempengaruhi aktivitasnya... Ibu pernah bercerita bahwa kalau ada resepsi di siang hari, Ibu dipesan olehnya (KH. Wahid Hasyim. Pen) agar mengambil makanan sedikit saja. Jadi, Bapak mengambil sedikit dan Ibu demikian. Setelah Ibu selesai makan, maka Bapak tanpa sepengetahuan orang menukar piringnya yang masih utuh dengan piring Ibu yang telah kosong. Lalu makanan yang beradsa di piring itu dihabiskan oleh Ibu pula. Orang-orang tak ada yang menyangka bahwa Bapak berpuasa." ${ }^{\prime 3}$

\section{Toleransi}

Nilai toleransi antar umat beragama diajarkan oleh KH. Wahid Hasyim melalui pidato pendirian Universitas Islam Sumatera Utara di Medan 1952, yang berjudul "Perguruan Tinggi Islam" :

“... Suatu hal yang menggembirakan di dalam pembukaan Perguruan Tinggi Islam ini perlu saya catat disini, bahwa walaupun Perguruan Tinggi ini memakai nama suatu agama tertentu, yaitu Islam, diantara tenaga-tenaga yang memajukannya, baik dikalangan pengajar maupun dikalangan pengajarnya, terdapat orang-orang dari macam-macam golongan agama. Kiranya ini suatu permulaan yang baik bagi kebebasan pikiran dari ikatanikatan perasaan yang timbul karena perbedaan kepercayaan dan agama. Maka patutlah dikemukakan harapan disini, bahwa perasaan harga-menghargai dan

${ }^{36}$ H. Aboebakar, Sedjarah..., 281.

37 Ali Yahya, Sama Tapi Berbeda Potret Keluarga Besar KH. A. Wahid Hasyim, (Jombang: Yayasan K.H. A. Wahid Hasyim, 2007), 110. 
Rangga Sa'adillah S. A. P.

kerjasama yang baik itu, dapat dipelihara selanjutnya. Bukan saja dalam batas lingkungan Perguruan Tinggi Islam ini, akan tetapi kiranya dapat pula disebarluaskan keluar dan diisikan kepada pelajar-pelajar dan siswa-siswa untuk mereka itu, khususnya dan untuk generasi yang akan datang umumnya .."38

Dalam sambutan tersebut KH. Wahid Hasyim mengajarkan umat Islam saling bertoleransi dengan agama lain. Menghargai hubungan emosional antara satu dengan yang lain. Dan tetap menekankan kerjasama walaupun berbeda kepercayaan atau agama. Sikap toleransi terhadap pemeluk agama lain merupakan sikap yang luhur serta dapat memupuk rasa persatuan antar manusia yang berbeda agama.

Dalam tulisan yang lain KH. Wahid Hasyim tidak mempermasalahkan kerjasama dengan pemeluk agama lain asalkan hal tersebut tidak menyangkut permasalahan prinsipil (aqidah). Dia mencontohkan sejarah pada Khalifah Harun al-Rasyid dan Khalifah alMa'mun. Keduanya adalah Raja Islam yang taat. Meskipun demikian, AlRasyid dan Al-Ma'mun tidak kaku dalam beragama, keduanya mengambil tenaga ahli dari orang yang beragama Nasrani. Keterangan ini sebagaimana terdapat dalam tulisan KH. Wahid Hasyim berikut:

“... Orang yang mempelajari Chalifah dari Harun Rasyid (lahir pada tahun 763 dan meninggal tahun 809 Masehi) pasti mengetahui, bahwa dokter kepala padanya adalah seorang beragama masehi, dan bahwa kepala gedung perpustakaan Chalifah Ma'mun (lahir pada tahun 786 dan meninggal pada tahun 833), juga seorang Nasrani. Banyak sekali kedudukan-kedudukan yang penting diserahkan pada orang-orang diluar kalangan muslimin." ${ }^{\prime 39}$

Melengkapi penjelasan di atas Arif ${ }^{40}$ memerinci karakter toleransi yang diajarkan oleh KH. Wahid Hasyim. Meskipun KH. Wahid Hasyim beragama Islam, dia berupaya menghormati dan menghindarkan diri untuk melakukan caci maki terhadap orang-orang yang berbeda pemahaman keagamaannya, bahkan ketika semua orang Yahudi melakukan penghinaan

\footnotetext{
38 Aboebakar, Sedjarah..., 808-809., Lihat Buntaran Sanusi, K.H.A. Wahid..., 81-82.

${ }^{39}$ Aboebakar, Sedjarah..., 677-679.

40 Moch. Choirul Arif, Tesis, KH. Abdul Wahid Hasyim (1914-1953) Wawasan Keislaman dan Kebangsaan, (Surabaya: Program Pascasarjana Institut Agama Islam Negeri Sunan Ampel, 2003), 59-60.
}

Jurnal Pendidikan Agama Islam

Volume 3 Nomor 2 November 2015

ISSN: 2089-1946

Hal. 288 - 303 
terhadap Nabi Isa AS., dia melakukan pembelaan dengan memberikan pengakuan bahwa Nabi Isa AS. adalah Rasul Allah yang mulia:

“...Bukankah Nabi Muhammad SAW. itu yang menegakkan pengakuan pada Nabi Isa AS. sebagai pesuruh Allah? Oleh orang yang hidup di jaman Beliau yaitu orang Yahudi, Nabi Isa bin Maryam AS., itu digambarkan sebagai seorang yang jahat, berkelakuan buruk dan dari keturunan yang tidak baik. Tapi Nabi Muhammad SAW. Beliau diakui sebagai pesuruh Allah yang mulia. Walaupun pada waktu itu kepentingan umat Islam dan penganut-penganut Nabi Isa bin Maryam AS. bertentangan, tetapi Nabi Muhammad SAW. tidak kehilangan pertimbangan yang adil, dan mengakui kebenaran sebagai hakikat yang harus diperhatikan." 41

\section{Mandiri}

Penanaman karalter mandiri terdapat dalam tulisan KH. Wahid Hasyim yang berjudul "Abdullah Ubaid Sebagai Pendidik". Artikel ini dimulai dengan menceritakan bagaimana Wahid Hasyim menerima tamu bernama Abdullah Ubaid bersama dua anaknya. Dalam pertemuan ini kemudian terjadilah cerita pendidikan sederhana, tetapi bermakna tinggi ketika sang tuan rumah menyediakan minuman teh dan sang tamu, terutama si anak hendak meminumnya.

Ketika itu si anak kecil meminta diberi minum teh, bapaknya kemudian berkata kepada anaknya, "Itu air tehnya sudah tersedia, minumlah." Si anak lalu berkata bahwa airnya masih panas. Sang Bapak menjawab tuangkalah ke piring cangkir. Si anak menyatakan ia takut nanti jika air tehnya tumpah. Maka, si bapak menjawab, "Tumpah pun tidak apa-apa, toh yang tuan rumah tidak akan marah, bukankah begitu saudara (kepada Wahid Hasyim beserta keluarga)?" Sang tuan pun menjawab, "Tidak apa-apa".

Setelah itu, si anak kemudian menuangkan air tehnya ke piring dan menunggu beberapa saat, setelah agak dingin, maka ia berkata, "Bapak, tolonglah minumkan air tehnya ini kepada saya." Sang bapak menjawab, "Minumlah sendiri, engkau sudah pintar meminum, jangan takut akan tumpah." Si anak menjawab, "Kalau tumpah nanti pakaian akan jadi kotor, jika kotor nanti akan diganti yang bersih (dan memang si anak membawa pakaian ganti)." Akan tetapi, nyatanya air teh yang diminumnnya tidak tumpah. ${ }^{42}$

Mengenai tulisan ini, KH. Saifuddin Zuhri berpendapat bahwa kisah sederhana tersebut amat penting artinya bagi seorang guru maupun bagi

${ }^{41}$ Aboebakar, Sedjarah..., 677-679.

42 Lebih lengkapnya tulisan ini bisa di lihat di Aboebakar, Sedjarah..., 791. 
Rangga Sa'adillah S. A. P.

seorang ayah atau ibu. Kepada anak harus ditanamkan kepercayaan pada dirinya sendiri, dimulai dari perkerjaan-pekerjaan yang kecil dan mudah. Guru maupun orang tualah yang harus membangkitkan semangat berani berbuat sambil diberikan petunjuk agar dapat dikerjakan dengan baik. ${ }^{43}$

\section{Demokratis}

Karakter demokratis mengembangkan sikap saling memahami, menghormati, atau toleransi antara orang yang satu dan yang lain, terutama terkait dengan hak dan kewajiban. Tanpa karakter demokratis ini, akan muncul pola kehidupan yang saling memaksa, tidak menghormati hak dan kewajiban orang lain, dan menomorsatukan kepentingan diri sendiri. ${ }^{44}$

KH. Wahid Hasyim mengajarkan bagaimana umat Islam agar berpikir secara demokratis. Sebab bagi KH. Wahid Hasyim, Islam mengajarkan kepada umatnya untuk berpikir demokratis namun tidak terlepas dari logika dan mantik (ilmu berargumen). Berpikir secara demokratis merupakan cara berpikir yang bebas dari perasaan sentimen, dalam al-Quran sendiri terdapat cemooh pedas kaum kafir terhadap Nabi Muhammad, seperti Nabi Muhammad adalah orang yang gila. Saat itu kaum kafir merasa sentimen pada ajaran yang dibawa oleh Nabi Muhammad hingga kehabisan argumen untuk menangkis ajaran haq yang dibawa oleh Nabi Muhammad. Sampai akhirnya hanya kata-kata cemooh yang bisa mereka keluarkan. Kata cemooh tersebut tidak dihilangkan atau disensor dalam al-Quran, akan tetapi tetap termuat. Melalui tulisan ini KH. Wahid Hasyim mengajarkan untuk tidak sentimen terhadap orang lain. Karena sikap sentimen membawa kerugian pada diri sendiri. Selain itu, berpikir secara demokratis bagi KH. Wahid Hasyim adalah menghormati hak dan kewajiban orang lain, seperti yang terdapat dalam tulisannya yang berjudul "Tuntutan Berfikir":

“... Sedemikian kerasnya Islam mengajari berpikir secara demokratis dengan menggunakan logika dan mantik, sehingga dalam al-Quran sendiri banyak dimuat kritik-kritik orang pada Nabi Muhammad S.A.W. Umpamanya seperti wayaquuluuna innahuu lamajnuun. Mereka itu mengatakan bahwa Nabi Muhammad itu adalah gila... dimaksudkan untuk memberikan pelajaran bahwa makian-makian demikian tidak akan merugikan, kecuali pada orang yang mengeluarkan sendiri dan bahwa pada akhirnya toh, akan dan pikiranlah yang akan mendapat kemenangan. Dan perasaan serta sentimen adalah merugikan

\footnotetext{
43 Syaifuddin Zuhri, Guruku..., 180.

${ }^{44}$ Akhmad Muhaimin Azzet, Urgensi...,93-94.

Jurnal Pendidikan Agama Islam

Volume 3 Nomor 2 November 2015

ISSN: 2089-1946

Hal. 290 - 303
} 
bagi orang yang mengandungnya sendiri, lebih banyak daripada bagi yang dibencinya." 45

KH. Wahid Hasyim begitu menegaskan bahwa Islam memang benarbenar demokratis, tidak takut pada pendapat orang lain yang berbeda haluan. Bahkan dia beriktikad bahwa tidak ada buku yang lebih demokratis dari pada al-Qur'an. Dia menjelaskan bahwa ayat "Wa yaquluuna innahu lamajnuun" (mereka lawan Muhammad, mengatakan bahwa sesungguhnya Muhammad itu adalah gila). Bagi KH. Wahid Hasyim, ayat tersebut dipertontonkan alQuran pada umat Islam dengan pengharapan supaya mereka dapat melihat, bahwa otak manusia itu ada juga yang demikian tololnya mereka kehabisan hujjah (argumen) didalam bertukar pikiran lalu memakai kata-kata kotor dan maki-makian. ${ }^{46}$

\section{Semangat Kebangsaan}

Perwujudan dari karakter semangat kebangsaan adalah sikap nasionalisme. Menurut Chodir ${ }^{47}$ dalam mewujdukan semangat nasionalisme, KH. Wahid Hasyim menentang paham primordialistik. Dalam tulisannya, KH. Wahid Hasyim menjelaskan:

“... Sikap dan semangat bergolong-golong itu didalam lingkungan Tanah Air kita, apabila diterus-teruskan akan berakibat rusaknya kemurnian persaudaraan kita sebangsa. Kita perlu mempunyai persatuan bangsa yang kokoh teguh. Lebih-lebih sebelumnya kemerdekaan datang. Maka fanatisme, ta'asub atau kekolotan dari segala fisik jangan dikeluarkan, supaya persatuan bangsa tidak terganggu dan tidak akan menjadi bangsa yang mentah. Kita tidak berkeberatan orang mengemukakan pahamnya, bahkan orang harus mempertahankan pendiriannya. Hanya saja fanatisme, kekolotan atau ta'asub janganlah dibawa-bawa. Salah satu dari macam-macam paham di Indonesia tentu akan mendapat kemajuan nanti. Bagi penganut paham ini kejadian itu tidak usah menjadi kesombongan, dan bagi penganut paham lainnya tidak usah hal itu menjadikan kecil hati. Sebab paham yang melebihi paham lainnya itu bukti, bahwa paham itu kuat. Penganut-penganutnya banyak berbuat dari pada beromong dan berkata."

\footnotetext{
${ }^{45}$ Aboebakar, Sedjarah..., 827. Lihat Buntaran Sanusi, K.H.A. Wahid..., 75.

46 Buntaran Sanusi, K.H.A. Wahid..., 32. KH. Abdul Wahid Hasyim, "Fanatisme dan Fanatisme" dalam Ibid., 42.

47 Fatkul Chodir, Pemikiran..., 56.
} 
Masih berkaitan dengan tulisan di atas, pada kesempatan terpisah KH. Wahid Hasyim menambahkan bahwa, di dalam sejarah sering kita jumpai perselisihan dan perbantahan. Jika kita teliti pemantik perselisihan tidak lain adalah sifat fanatik dan ta'assub. ${ }^{48}$

Sikap semangat kebangsaan, juga dia tunjukkan tatkala memperjuangkan bentuk dan dasar Negara Indonesia dalam sidang BPUPKI (Badan Penyelidikan Usaha-Usaha Persiapan Kemerdekaan IndonesiaDokuritsu Zumbi Tyoosakai). Sebagai perwakilan dari kalangan Nasionalis Islami KH. Wahid Hasyim mengajukan beberapa usul penting: presiden harus orang Islam, serta mencanangkan Islam sebagai agama negara. Dilain pihak, kalangan Islami juga menyodorkan Piagam Jakarta yang akhirnya disetujui oleh dua kelompok nasionalis Islam dan sekuler.

Namun pada tahap berikutnya, tepat sehari sebelum proklamasi KH. Wahid Hasyim berubah pikiran. Ia berbalik mendukung untuk menghapus tujuh kata dalam Mukaddimah UUD (...kewajiban menjalankan syariat Islam bagi pemeluk-pemeluknya) ${ }^{49}$ padahal awalnya KH. Wahid Hasyim begitu getol memperjuangkan tujuh kata tersebut. Pemikiran KH. Wahid Hasyim bukanlah merupakan pemikiran yang inkonsistensi, melainkan disinilah letak kebesaran jiwa seorang KH. Wahid Hasyim, dia menempatkan kepentingan bangsa di atas kepentingan lain. Hal tersebut merupakan wujud dari sikap semangat kebangsaan yang tinggi. 50

\section{Cinta Tanah Air}

Sebagai wujud implementasi sikap Cinta Tanah Air, KH. Wahid Hasyim menjunjung tinggi Bahasa Indonesia, bagi KH. Wahid Hasyim kemajuan bahasa juga merupakan kemajuan bangsa. Dalam tulisannya yang berjudul "Kemajuan Bahasa Berarti Kemajuan Bangsa" dia menyayangkan pemuda-pemuda kota yang lebih bangga menggunakan bahasa asing dalam menegur sapa dengan koleganya dari pada menggunakan bahasa sendiri. Mereka yang menggunakan bahasa asing tersebut hanyalah alasan prestisius saja paranhnya mereka mulai tidak menunjukkan rasa bangganya terhadap Bahasa Indonesia. Seharusnya sebagai bangsa Indonesia yang cinta terhadap

\footnotetext{
48 Ibid., 57.

${ }^{49}$ Dalam mukaddimah UUD 1945 terdapat kata-kata "Berdasarkan kepada Ketuhanan, dengan kewajiban menjalankan syariat Islam bagi pemeluk-pemeluknya." Mengenai mukaddimah UUD tersebut kelompok nasionalis sekuler keberatan dengan adanya tujuh kata yang berbunyi..."dengan kewajiban menjalankan syariat Islam bagi pemeluk-pemeluknya."

50 Lebih lengkapnya mengenai penjelasan ini, proses bagaimana KH.Abdul Wahid Hasyim berbalik arah dapat di baca di Rijal Mumazziq Z., Relasi..., 53-95.
} 
tanah air bahasa yang digunakan adalah Bahasa Indonesia. Berikut yang diungkapkan KH. Wahid Hasyim:

"Bagi orang yang berdiam dikota atau yang acapkali berkunjung ke kota, niscaya akan membenarkan perkataan penulis ini. Bukankah kerap kali benar, ia bahkan boleh dikata saban pagi sebagian dari kaum muda kita, ... senang mengucapkan kalimat Good Morning atau Goeden Margen dan entah Good apa lagi, dari pada melafadkan Selamat Pagi. Teristimewa kalau bertemu dengan seorang kawannya, seolah-olah berat, tak kuasa dan bagaikan kelu lidahnya apakala ditegur dengan Apa Kabar? Sedang wajahnya membayang muram; tetapi bilamana ditegur How Do You Do? Atau Hoe Maak Je't? Riangnya bukan main dan seketika itu juga dijawab denga lancar dan fasih, seakan-akan tiada merasa berat dan kemalasannya hilang seketika! (ganjil bukan?). Nah sekianlah perbedaan bahasa kita dengan bahasa asing itu. Hanyalah sebagai bukti bahwasanya kemajuan bangsa itu berarti kemajuan bangsa, dan bukanlah keterangan penulis yang demikian itu penuh berkehendak merendahkan pada mereka yang tergila-gila barat itu bukan, pun bukanlah berarti bahwasanya penulis benci atau tiada setuju dengan orang yang berbahasa asing itu sekali-kali bukan. Penulis senang kepada orang belajar bahasa asing dan setuju juga, kecuali termasuk kewajiban sebagai putera Timur yang muslim, yang diharuskan menuntut akan sekalian kepandaian yang ada diatas dan ilmu pengetahuan yang beraneka ragam itu, pun penulis pernah juga belajar sekalipun hanya satu One dua One atau se-Een dua Een, tetapi dalam selama kita belajar itu, kita harus tetap mempunyai anggapan dan kepercayaan bahwasanya kita putra Indonesia. Kita mempunyai bahasa sendiri, sedang kita belajar bahasa asing itu hanya sekedar untuk mengetahui belaka, tidak lain!!!..."51

Lebih jauh dalam tulisan yang sama KH. Wahid Hasyim mencontohkan Adolf Hitler seorang tokoh Nazi dari Negara Jerman mampu yang memprovokasi dan meledakkan Perang Dunia II, saat berunding dengan Nevile Chamberlain lebih memilih menggunakan Bahasa Jerman, meskipun Hitler lancar menggunakan Bahasa Inggris namun dia lebih bangga menggunakan bahasa tanah airnya sendiri. Begitu juga Nevile Chamberlain Perdana Menteri Kerajaan Inggris ketika berunding dengan Hitler lebih bangga menggunakan Bahasa Inggris, padahal Chamberlain mampu berbahasa Jerman. Keduanya ketika berunding lebih memilih jasa juru bahasa

${ }^{51}$ Aboebakar, Sedjarah..., 798. Lihat Buntaran Sanusi, K.H.A. Wahid..., 66. 
Rangga Sa'adillah S. A. P.

daripada menggunakan bahasa negara lain. Berikut komentar KH. Wahid Hasyim:

“... Perdana Menteri Kerajaan Inggris Nevile Chamberlain .... Adolf Hitler. Kedua orang besar ini beberapa tahun yang telah lampau, ... kedua orang besar ini sudah pernah bertemu muka berhadap-hadapan di suatu tempat yang telah disediakan untuk itu. Pertemuan guna berunding mencari upaya untuk mencegah pecahnya bisul internasional. Disini kita tiada akan membentangkan (menjelaskan. Pen) tentang bagaimanakah cara kedua orang besar ini memutarbalikkan politik internasional,... Tetapi disini kita hendak membicarakan dengan bahasa apakah gerakan kedua orang besar ini mengeluarkan pendapat masing-masing? ... Masing-masing menggunakan bahasanya sendiri. Adolf Hitler mempergunakan Bahasa Jermannya sedang Nevile Chamberlain pun memakai Bahasa tanah airnya, yakni Inggris padahal Chamberlain ini dapat dan pandai berbahasa Jerman sedang Hitler pun amat lancar berbahasa Inggris..." 52

Dengan bangga menggunakan bahasa sendiri (Bahasa Negara) ini merupakan wujud kebanggaan terhadap tanah air, wujud kebanggaan terhadap tanah air merupakan wujud dari sikap kecintaan terhadap tanah air.

\section{Bersahabat/ Komunikatif}

Sikap bersahabat dan komunikatif dia tunjukkan kepada siapapun. Tidak peduli orang tersebut muslim ataupun non-Muslim. KH. Abdurrahman Wahid (anaknya) memberikan kesaksian atas sikap ayahnya yang begitu mempunyai hubungan baik dengan orang-orang dari berbagai kalangan:

"Perhatian Bapak yang besar bukan hanya kepada keluarga Beliau juga bersikap demikian kepada setiap orang dan juga memiliki hubungan yang sangat baik dengan barbagai kalangan. Kawan-kawannya bukan hanya dari kalangan muslim saja, melainkan non-Muslim..."53

Kesaksian lain dituturkan oleh KH. Sholahuddin Wahid, bahwa ayahnya berkawan dengan banyak orang dan tidak membedakan agama, suku, pendidikan, bahkan haluan politik sekali pun. Wujud sikap KH. Wahid Hasyim tetap setia bersahabat dan menjalin silaturrahim kepada orang lain, dia tunjukkan ketika NU mulai memisahkan diri dengan Masyumi. Meskipun

52 Buntaran Sanusi, K.H.A. Wahid..., 67.

53 Ali Yahya, Sama Tapi Berbeda Potret Keluarga Besar KH. A. Wahid Hasyim, (Jombang: Yayasan K.H. A. Wahid Hasyim, 2007), 80.

Jurnal Pendidikan Agama Islam

Volume 3 Nomor 2 November 2015

ISSN: 2089-1946

Hal. 294 - 303 
secara pribadi KH. Wahid Hasyim tidak setuju, namun karena hal ini merupakan keputusan dari Muktamar NU dia selaku tokoh NU pada masa itu dengan besar hati menyetujui keputusan tersebut dan tetap menjaga silaturrahim dengan Masyumi. Berikut penuturan KH. Sholahuddin Wahid:

"... Beliau berkawan dengan banyak orang dari berbagai kalangan tanpa membedakan latar belakang agama, suku, pendidikan, dan politik. Praktis Bapak tidak mempunyai musuh politik apalagi musuh pribadi. Lawan politik (yang berbeda sikap dan pendirian politik) tetap menjadi kawan secara pribadi. Kondisi semacam ini pada waktu itu memang sesuatu yang sifatnya umum. Ketika NU dan Masyumi mengalami masa sulit, hubungan Beliau dengan tokoh Masyumi masih tetap terjalin dengan baik... Bapak tidak setuju NU keluar dari Masyumi. Tetapi karena mayoritas peserta Muktamar dengan dimotori KH. Wahab Hasbullah menghendaki NU keluar, maka Bapak pun mengikutinya. Hebatnya, Beliau sendiri yang kemudian menyampaikan keputusan muktamar itu ke Pak Natsir. Beliau tidak mencampuradukkan antara kepentingan sendiri dengan kepentingan organisasi." ${ }^{54}$

Sikap bersahabat kepada semua kalangan ini pun disertai dengan sikapnya yang tidak membeda-bedakan orang. Aisyah Hamid Baidlowi putri KH. Wahid Hasyim mengakuinya bahwa Ayahnya mempunyai sikap yang demikian. Saat ada tamu dari siapapun baik itu menteri, Kiai, ketua parta, tetangga, sopir, dan sebagainya semua diterima dengan baik. Bahkan yang lebih mengagumkan adalah sikap santun KH. Wahid Hasyim kepada sopirnya yang bernama Usman, dia memanggil dengan sapaan Bang Usman tidak Usman saja. ${ }^{55}$

\section{Gemar Membaca}

KH. Wahid Hasyim merupakan sosok yang gemar membaca. Kebiasaan gemar membaca ini dia tunjukkan saat masih usia belia. Terlampau gemarnya dia dengan kebiasaan membaca saat dia masih berumur 12 tahun harus memakai kacamata. Zaini memberikan informasi dalam buku karangannya "K.H. Abdul Wahid Hasyim Pembaru Pendidikan Islam", bahwa KH. Wahid Hasyim juga tercatat sebagai anggota perpustakaan Surabaya. Tidak seperti anggota lainnya yang membaca berdasar sesuatu yang menjadi keinginan mereka, Wahid Hasyim membaca semua buku yang tersedia di perpustakaan, bahkan dilaporkan dia meminjam berdasarkan nomor buku secara berurutan. Sayangnya, informasi berkaitan dengan hal ini sangat

54 Ibid. 99-100.

55 Ibid., 86. 
Rangga Sa'adillah S. A. P.

sedikit. Bisa jadi benar bahwa dia membaca seluruh buku yang ada karena jumlah buku yang tersedia masih sangat terbatas, atau dia me-review buku tersebut untuk melihat isi buku, kemudian dia membaca secara selektif sesuai dengan minatnya. Singkat kata melalui autodidak, pengetahuan yang didapatnya sangat luas mulai tafsir, hadits, fiqih, sampai pengetahuan sejarah politik, dan filsafat.

Saat menjadi Kepala Madrasah Nizamiyah sikap gemar membaca ini benar-benar diwujudkan oleh KH. Wahid Hasyim kepada anak didiknya. Dia berusaha meningkatkan kebiasaan membaca dan kualitas pengetahuan siswa dengan cara mendirikan sebuah perpustakaan. Buku yang tersedia berjumlah kurang lebih 1.000 yang terdiri buku-buku teks dan karya-karya ilmiyah populer baik itu ditulis dalam bahasa Arab, Inggris, Belanda, Indonesia dan Jawa.

Untuk memperkaya wawasan dan informasi dia juga berlangganan majalah dan surat kabar, termasuk Panji Mas, Dewan Islam, Islam Bergerak, Adil, Nurul Islam, al-Munawwaroh, Berita Nahdlatul Ulama, Panji Pustaka, Pustaka Timur, Pudjangga Baru, dan Penjebar Semangat. ${ }^{56}$

\section{Relevasi Pemikiran Pendidikan Karakter Perspektif KH. Wahid Hasyim dengan Kondisi Saat Ini}

Pada uraian sebelumnya telah diketahui bahwa dalam pemikiran Pendidikan Karakter KH. Wahid Hasyim terdapat delapan nilai, yakni: Religius, Toleransi, Mandiri, Demokratis, Semangat Kebangsaan, Cinta Tanah Air, Bersahabat/Komunikatif, Gemar Membaca. 57

Dari delapan nilai tersebut pendekatan yang dilakukan oleh KH. Wahid Hasyim menggunakan penanaman nilai. Sejalan dengan yang dijelaskan oleh Muslich, pendekatan penanaman nilai berusaha memberikan penekanan pada penanaman nilai-nilai sosial dalam diri anak didik. ${ }^{58}$ Seperti apa yang dilakukan oleh KH. Wahid Hasyim yang berusaha memberikan teladan kepada anak didiknya. Maka lebih cocok strategi yang digunakan oleh KH. Abdul Wahid Hasyim

\footnotetext{
${ }^{56}$ Achmad Zaini, KH. Abdul..., 38.

57 Mengenai relevansi pemikiran pendidikan karakter KH. Abdul Wahid Hasyim, penulis rangkum dalam tulisan yang berjudul Nilai-Nilai Pendidikan Karakter Dalam Pemikiran KH. Wahid Hasyim. Lihat Rangga Sa'adillah, "Nilai-Nilai Pendidikan Karakter Dalam Pemikiran KH. Wahid Hasyim", dalam http://www.nu.or.id/a,public-m,dinamic-s,detail-ids,4-id,37747lang,id-c,kolom- t,Nilai+Nilai+Pendidikan+Karakter+dalam+Pemikiran+KH+Wahid+Hasyim.phpx, diakses pada tanggal 11 Mei 2012, pukul 21.31.

58 Masnur Muslich, Pendidikan..., 108.
}

Jurnal Pendidikan Agama Islam

Volume 3 Nomor 2 November 2015

ISSN: $2089-1946$

Hal. 296 - 303 
dalam menanamkan nilai pendidikan karakter adalah menggunakan strategi keteladanan nilai. ${ }^{59}$

Dalam berbagai pemikirannya tentang pendidikan KH. Wahid Hasyim menanamkan nilai-nilai sosial seperti toleransi, demokratis, bersahabat/ komunikatif sebagai acuan dalam bertingkahlaku dalam berinteraksi dengan sesama. ${ }^{60}$ Dengan nilai-nilai sosial yang diajarkan oleh KH. Wahid Hasyim dia ingin menyampaikan pesan bahwa sesungguhnya manusia adalah bersaudara satu sama lain. Nilai persaudaraan bagi KH. Wahid Hasyim merupakan tatacara manusia pertemanan apakah itu kepada antar negara, atau kepada orang yang terdiri dari berbagai latar belakang bahkan pada orang yang berprofesi dibawahnya. Dia juga menyadari bahwa bangsa Indonesia adalah bangsa yang multikultural. Disamping itu dia memberikan teladan agar belaku baik kepada siapa saja meskipun kepada anak buahnya. Seperti apa yang diungkapkan oleh anaknya yang bernama Aisyah Hamid Baidlowi, KH. Wahid Hasyim bila menyapa sopirnya dia memanggil dengan nama bang Usman.61 Selain itu dalam hubungan sosial KH. Wahid Hasyim menekankan sikap toleransi. Sikap toleransi ini merupakan sikap menghormati orang yang berkeyakinan (agama) tidak sama. Seperti yang ada dalam tulisannya untuk menyambut berdirinya Universitas Sumater Utara. Dia menghargai bahwa dalam pendirian Perguruan Tinggi Islam ada tenaga pengajar dan pelajarnya yang berlainan agama. Menghadapi kondisi tersebut dia menekankan sikap toleransi, bahkan dia memberikan apresiasi. ${ }^{62}$ Apa yang menjadi pemikiran KH. Wahid Hasyim tersebut tertuang dalam tujuan Pendidikan Karakter yang berusaha membangun kehidupan kebangsaan yang multikultural.63

KH. Wahid Hasyim juga mengajarkan karakter berkewarganegaraan. Dalam karakter berkewarganegaraan dia menekankan nilai-nilai semangat kebangsaan dan cinta tanah air. Dengan nilai tersebut, bagi KH. Wahid Hasyim merupakan cara untuk memajukan bangsa. Untuk menempatkan karakter cinta tanah air, dia menanamkan karakter yang paling ringan yakni cinta terhadap bahasa. Sehingga KH. Wahid Hasyim berkesimpulan kemajuan bahasa adalah kemajuan bangsa. Bagaimana tidak, dia mencontohkan Hitler dan Chamberlain ketika bernegoisasi menggunakan bahasa negara mereka masing-masing meskipun keduanya sama-sama menguasai bahasa lawannya. Dengan mencintai

\footnotetext{
${ }^{59}$ Baca Zubaedi, Desain..., 234.

${ }^{60}$ Mengenai penjelasan pendekatan penanaman nilai lihat Zubaedi, Desain..., 209.

${ }^{61}$ Ali Yahya, Sama..., 86.

62 Buntaran Sanusi, KH. A. Wahid..., 82.

63 Tim Penyusun, Panduan ..., 3.
} 
Rangga Sa'adillah S. A. P.

bahasa merupakan bukti kita mencintai tanah air kita.64 Semangat kebangsaan dia tunjukkan tatkala mengedepankan kepentingan bangsa dari pada pendapat pribadinya dalam sidang BPUPKI. Dia menyetujui untuk mengamandemen tujuh kata yang diperdebatkan dalam sidang tersebut. Kata yang diamandemen tersebut adalah "dengan kewajiban menjalankan syariat Islam bagi pemeluk-pemeluknya." Apa yang menjadi pemikiran KH. Wahid Hasyim ini juga terdapat dalam rumusan tujuan Pendidikan Karakter pada poin membangun sikap warganegara yang mencintai damai, kreatif, mandiri, dan mampu hidup berdampingan dengan bangsa lain dalam suatu harmoni. 65

Selain karakter sosial dan berkewarganegaraan KH. Wahid Hasyim juga mengajarkan karakter pengembangan diri. Karakter tersebut adalah mandiri, dan gemar membaca. Dengan karakter mandiri bagi KH. Wahid Hasyim anak didik mampu menghadapi pekerjaan yang sulit pada akhirnya tidak mudah minta bantuan terhadap orang lain. ${ }^{66}$ Mengenai karakter gemar membaca merupakan wujud dari karakter cinta pada ilmu pengetahuan. Penanaman karakter ini dia contohkan ketika menjadi Kepala Madrasah Nizamiyah. Dia membangun perpustakaan dan berlangganan surat kabar dari berbagai terbitan. Mengenai nilai karakter pengembangan diri tersebut relevan dengan apa yang menjadi tujuan Pendidikan Karakter membangun peradaban bangsa yang cerdas, berbudaya luhur, dan mempu berkontribusi terhadap pengembangan kehidupan ummat manusia, mengembangkan potensi dasar agar berhati baik, berpikiran baik, dan berperilaku baik serta keteladanan baik. ${ }^{67}$

Nilai karakter terakhir yang ditanamkan oleh KH. Wahid Hasyim adalah religius. Nilai religius ini merupakan nilai yang menjadi landasannya dalam bersikap. Dalam berbagai tulisan dan pemikirannya, KH. Wahid Hasyim selalu mengkaitkan dengan keagamaan (Islam). Posisinya sebagai ulama mempertegas nilai karakter religius tersebut. Nilai ini sejalan dengan yang disampaikan oleh Sudrajat bahwa Pendidikan karakter adalah sebuah sistem yang menanamkan nilai-nilai karakter pada peserta didik, mengandung komponen pengetahuan, kesadaran individu, tekat, serta adanya kemauan dan tindakan untuk melaksanakan nilai-nilai, baik terhadap Tuhan Yang Maha Esa, diri sendiri, sesama manusia, lingkungan maupun bangsa, sehingga akan terwujud insan kamil.68

${ }^{64} \mathrm{KH}$. A. Wahid Hasyim, "Kemajuan Bahasa Berarti Kemajuan Bangsa", dalam Buntara Sanusi (ed), Mengapa Memilih NU..., 65-70

65 Tim Penyusun, Panduan ..., 3.

${ }^{66}$ KH. A. Wahid Hasyim, "Abdullah Ubaid Sebagai Pendidik", dalam H. Aboebakar, Sedjarah..., 791-797.

67 Tim Penyusun, Panduan ..., 3.

68 Nurla Isna Aunillah, Panduan Menerapkan Pendidikan Karakter di Sekolah, (Jogjakarta: Laksana, 2011), 19. Bandingkan dengan Akhmad Sudrajat, "Tentang Pendidikan Karakter", 
KH. Wahid Hasyim merupakan konseptor pendidikan Islam yang ulung. Gagasan-gagasan serta pemikiran-pemikirannya tentang pendidikan Islam masih relevan dengan keadaan saat ini. Mengenai relevansi pemikiran pendidikan Islam KH. Wahid Hasyim, Dhofier mengatakan bahwa madrasah-madrasah serta pondok pesantren modern saat ini yang memadukan antara ilmu agama dengan ilmu umum merupakan pengembangan gagasan dari prototype Madrasah Nizamiyah yang menjadi pilot project $\mathrm{KH}$. Wahid Hasyim dalam mengembangkan pesantren Tebuireng.

\section{Penutup}

Dari analisis yang penulis lakukan terhadap pemikiran Pendidikan $\mathrm{KH}$. Abdul Wahid Hasyim, ada delapan nilai-nilai yang berusaha ditanamkan oleh KH. Abdul Wahid Hasyim dalam pemikiran pendidikannya. Delapan nilai tersebut adalah Religius, Toleransi, Mandiri, Demokratis, Semangat Kebangsaan, Cinta Tanah Air, Bersahabat/Komunikatif, Gemar Membaca.

Nilai-nilai Pendidikan Karakter yang diajarkan oleh KH. Abdul Wahid Hasyim sejalan dengan tujuan Pendidikan Karakter yakni membangun kehidupan kebangsaan yang multikultural; membangun peradaban bangsa yang cerdas, berbudaya luhur, dan mampu berkontribusi terhadap pengembangan kehidupa ummat manusia, mengembangkan potensi dasar agar berhati baik, berpikira baik, dan berperilaku baik serta keteladanan baik; membangun sikap warganegara yang mencintai damai, kreatif, mandiri, dan mampu hidup berdampingan dengan bangsa lain dalam suatu harmoni.

\section{E. Daftar Pustaka}

. Kebijakan Nasional Pendidikan Karakter Bangsa 2010-2025. Di akses di http://nasuprawoto.wordpress.com/2010/10/25/downloadkebijakan-nasional-pendidikan-karakter-bangsa-2010-2025/konseppend-karkater-puskur/

Panduan Umum Penyusunan Kurikulum Tingkat Satuan Pendidikan (KTSP). Surabaya. Kantor Wilayah Departemen Agama Provinsi Jawa Timur. 2006.

Peraturan Pemerintah Republik Indonesia Nomor 55 Tahun 2007 Tentang Pendidikan Agama dan Pendidikan Keagamaan. Jakarta: Direktorat Pendidikan Diniyah dan Pondok Pesantren Direktorat Jenderal Pendidikan Islam Departemen Agama RI. 2008.

dalam $\quad$ http://akhmadsudrajat.wordpress.com/2010/08/20/pendidikan-karakter-di-smp, diakses pada tanggal 10 Desember 2011, pukul 09.45 WIB. 
Rangga Sa'adillah S. A. P.

- Standar Nasional Pendidikan Peraturan Pemerintah Republik Indonesia Nomor

19 Tahun 2005 Tentang Standar Nasional Pendidikan. Surabaya:

Departemen Agama Kantor Wilayah Provinsi Jawa Timur. 2005. . Undang-Undang Republik Indonesia Nomor 20 Tahun 2003 Tentang Sistem

Pendidikan Nasional. Jakarta: BP. Dharma Bhakti.

. 12 Pilar Pendidikan Utuh dan Menyeluruh. Diakses di

http://www.pendidikankarakter.org/12\%20Pilar.html . http://www.nu.or.id/page.php.

A., Doni Koesoema. Pendidikan Karakter di Zaman Kebelinger. Jakarta: Grasindo. 2009.

Arif, Moch. Choirul. K.H. Abdul Wahid Hasyim (1914-1953) Wawasan Keislaman dan Kebangsaan. Surabaya: Program Pasca Sarjana IAIN Sunan Ampel Surabaya. Konsentrasi Bidang Pemikiran Islam. 2003.

Arifin, Muzayyin. Filsafat Pendidikan Islam. Jakarta: Bumi Aksara. 2005.

Arifin, M. Ilmu Pendidikan Islam Tinjauan Teoretis dan Praktis Berdasarkan Pendekatan Interdisipliner. Jakarta: Bumi Aksara. 2008.

Arikunto, Suharsimi. Prosedur Penelitian Suatu Pendekatan Praktik. Jakarta: Rineka Cipta. 2006.

Ash Shidqi, Hasbi. Pendidikan Akhlak Menurut KH. Imam Zarkasyi dan Relevansinya Dengan Pendidikan Karakter Bangsa. Surabaya: Program Pasca Sarjana IAIN Sunan Ampel Surabaya. Konsentrasi Pendidikan. 2010

Atjeh, Aboebakar. Sejarah Hidup K.H.A.Wahid Hasyim danKarangan Tersiar. Jakarta: Panitia Buku Pering $124 \quad$ K.H.A. Wahid Hasyim. 1957.

Aunillah, Nuria Isna. Panduan Menerupкuı Pendidikan Karakter di Sekolah. Yogyakarta: Laksana. 2011.

Azzet, Akhmad Muhaimin. Urgensi Pendidikan Karakter di Indonesia. Yogyakarta: Ar-Ruzz Media. 2011.

Basri, Hasan. Filsafat Pendidikan Islam. Bandung: Pustaka Setia. 2009.

Chodir, Fatkul. Pemikiran K.H. A. Wahid Hasyim Tentang Nasionalisme Dalam Konteks Fiqih Siyasah. Surabaya: IAIN Sunan Ampel Surabaya Fakultas Syariah Jurusan Siyasah Jinayah. 2010.

Darajat, Zakiah. Ilmu Pendidikan Islam. Bandung: Bumi Aksara. 2008.

Dari Surat Kabar, Majalah, Koran, atau Jurnal

Dhofier, Zamakhsyari. Tradisi Pesantren Studi Pandangan Kyai dan Visinya Mengenai Masa Depan Indonesia. Jakarta: LP3ES. Cet ke-8. 2011.

Iskandar, Metodologi Penelitian Pendidikan dan Sosial (Kuantitatif dan Kualitatif). Jakarta: Gaung Persada Press. 2010. 
Jamilah, Siti Malihatun. Perjuangan dan Peranan Dakwah KH. A. Wahid Hasyim. Semarang: Fakultas Dakwah Institut Agama Islam Negeri Walisongo. 1998.

Khisbiyah, Lailatul. Penerapan Pendidikan Karakter Jujur Melalui Kantin Kejujuran di SMA Negeri 3 Sidoarjo. Surabaya: IAIN Sunan Ampel Surabaya Fakultas Dakwah Jurusan Psikologi. 2011.

Kriswandono, Muhammad. Implementasi Pendidikan Berbasis Karakter Anak Sebagai Upaya Mengefektifkan Proses Pembelajaran di Sekolah Dasar Islam Al-Azhar Kepala Gading Surabaya. Surabaya: IAIN Sunan Ampel Surabaya Fakultas Tarbiyah Jurusan Kependidikan Islam. 2011.

Madjid, Abdul, Dian Andayani. Pendidikan Karakter Perspektif Islam. Bandung: Remaja Rosdakarya. 2011.

Marimba, Ahmad D. Filsafat Pendidikan Islam. Bandung: Al-Ma'arif. 1962.

Mimbar Pembangun Agama No. 279 Dzulhijjah - Muharram. Th 1430-1431 H/ Desember 2009 Th. XXXIX.

Mimbar Pembangun Agama No. 296 Jumadil Awal - Jumadil Akhir. Th 1432 H/ Mei 2011 Th. XXXIX.

Mimbar Pembangun Agama No. 297 Jumadil Akhir - Rajab. Th 1432 H/ Juni 2011 Th. XXXIX.

Mimbar Pembangun Agama No. 299 Ramadhan - Syawal. Th 1432 H/ Agustus 2011 Th. XXXIX.

Mimbar Pembangun Agama. No. 298 Jumadil Akhir-Rajab. Th 1432 H/ Juli 2011 Th. XXXIX.

Mimbar Pembangun Agama. No. 302 Dzulhijah - Muharram. Th 1432 H/ November 2011 Th. XXXXI.

Moeloeng, Lexy J. Metodologi Penelitian Kualitatif. Bandung: Rosda Karya. 2002.

Moesa, Ali Maschan. Nasionalisme Kiai Konstruk Sosial Berbasis Agama. Yogyakarta: LkiS. cet.II 2011.

Mu'in, Fatchul. Pendidikan Karakter Konstruksi Teoretik dan Praktik. Yogyakarta: Ar-Ruzz Media. 2011.

Muhadjir, Noeng. Metode Penelitian Kualitatif. Yogyakarta: Rake Sarasin.1996.

Mulyana, Dedi. Metodologi Penelitian Kualitatif. Bandung: Remaja Rosdakarya. 2004.

Munawaroh, Shabahatul. Pola Pembentukan Karakter Anak Melalui Pendidikan Ramah Anak Dalam Perspektif Pendidikan Agama Islam. Surabaya: IAIN Sunan Ampel Surabaya Fakultas Tarbiyah Jurusan Pendidikan Agama Islam. 2009.

Muslich, Masnur. Pendidikan Karakter Menjawab Tantangan Krisis Multidimensional. Bandung: Bumi Aksara. 2011. 
Rangga Sa'adillah S. A. P.

Nata, Abudin. Filafat Pendidikan Islam. Jakarta: Logos. 1997.

Punggeti, Hasran. Pengaruh Pendidikan Karakter Dalam Menanggulangi Deliquency Siswa Kelas VIII di SMP Al-Islam Surabaya. Surabaya: IAIN Sunan Ampel Surabaya Fakultas Tarbiyah Jurusan Pendidikan Agama Islam. 2011.

Rahardjo, Suparto. Ki Hajar Dewantara Biografi Singkat 1889-1959. Yogyakarta: Garasi. 2009.

Rifa'i, Mohammad. Wahid Hasyim Biografi Singkat 1914-1953. Yogyakarta: Garasi. 2009.

Rifa'i, Muhammad. Sejarah Pendidikan Nasional. Yogyakarta: Ar-Ruzz Media. 2011. Roziqin, dkk. 101 Tokoh Islam Indonesia. Yogyakarta: e-Nusantara. 2009.

Sanusi, Buntaran (ed), dkk. K. H. A. Wahid Hasyim Mengapa Memilih NU? Konsepsi Tentang Agama, Pendidikan dan Politik. Jakarta: PT Inti Sarana Aksara. 1985.

Sudijono, Anas. Pengantar Statistik Pendidikan. Jakarta: Rajawali Grafindo Persada. 2009.

Sudrajat, Akhmad. Degradasi Moral dan Prinsip Pendidikan Karakter. Diakses di http://akhmadsudrajat.wordpress.com/2011/07/31/degradasi-moraldan-prinsip-pendidikan-karakter/

Sudrajat, Akhmad. Indikator Keberhasilan Program Pendidikan Karakter. Diakses di http://akhmadsudrajat.wordpress.com/2010/09/23/indikatorkeberhasilan-program-pendidikan-karakter/

Sudrajat, Akhmad. Konsep Pendidikan Karakter. Diakses di http://akhmadsudrajat.wordpress.com/2010/09/15/konseppendidikan-karakter/

Sudrajat, Akhmad. Pendidikan Karakter di SMP. Diakses di http://akhmadsudrajat.wordpress.com/2010/08/20/pendidikankarakter-di-smp/

Sulistiawati, Dia. Pengaruh Pelaksanaan Pendidikan Karakter Pilar Hormat dan Santun Terhadap Sopan Santun Siswa di TK Karakter Amanah Jombang. Surabaya: IAIN Sunan Ampel Surabaya Fakultas Tarbiyah Jurusan Pendidikan Agama Islam. 2008.

Suyanto. Urgensi Pendidikan Karakter. Diakses di http://waskitamandiribk.wordpress.com/2010/06/02/urgensipendidikan-karakter/

Tim Redaksi. Kamus Besar Bahasa Indonesia Edisi Ketiga. Jakarta: Departemen Pendidikan Nasional Balai Pustaka. 2000.

Tim. Bahan Pelatihan Penguatan Metodologi Pembelajaran Berdasarkan Nilai-Nilai Budaya Untuk Membentuk Daya Saing dan Karakter Bangsa Pengembangan Pendidikan Budaya dan Karakter Bangsa. Jakarta: 
Kementrian Pendidikan Nasional Badan Peneltian dan Pengembangan Pusat Kurikulum. 2010.

Tim. Panduan Pelaksanaan Pendidikan Karakter. Jakarta: Kementrian Pendidikan Nasional Badan Penelitian dan Pengembangan Pusat Kurikulum dan Perbukuan. 2011.

Trianto. Mendesain Model Pembelajaran Inovatif-Progresif. Jakarta: Kencana. 2010

Ulfa, Siti Maria. Implementasi Pendidikan Aqidah Akhlak Dalam Membentuk Karakter Siswa yang Baik. Surabaya: IAIN Sunan Ampel Surabaya Fakultas Tarbiyah Jurusan Pendidikan Agama Islam. 2011.

Uthman, Miftah Adebayo Olowokofayoku. K. H. Abdul Wahid Hasjim (1914-1953) His Educational and Religious Thought. Yogyakarta: IAIN Sunan Kalijaga.

Yahya, Ali. Sama Tapi Berbeda Potret Keluarga Besar K. H. A. Wahid Hasyim. Jombang: Yayasan K. H. A. Wahid Hasyim. 2007.

Yamin, Moh. Menggugat Pendidikan Indonesia. Yogyakarta: Ar-Ruzz Media. 2009.

Yatim, Badri. Sejarah Peradaban Islam Dirasah Islamiyah II. Jakarta: PT. Rajagrafindo Persada. Cet ke-22. 2010.

Zaini, Achmad. K.H. Abdul Wahid Hasyim Pembaru Pendidikan Islam. Jombang: Pesantren Tebuireng. 2011.

Zed, Mestika. Metode Penelitian Kepustakaan. Jakarta: Yayasan Obor Indonesia. 2004.

Zionis, Rijal Mumazziq. Relasi Agama dan Negara Dalam Perspektif KH. A. Wahid Hasyim dan Relevansinya Pada Kondisi Sekarang. Surabaya: IAIN Sunan Ampel Surabaya Fakultas Syariah Jurusan Siyasah Jinayah. 2010.

Zubaedi. Desain Pendidikan Karakter Konsepsi dan Aplikasi Dalam Lembaga Pendidikan. Jakarta: Kencana. 2011.

Zuhairini, dkk. Filsafat Pendidikan Islam. Jakarta: Bumi Aksara. 1991.

Zuhairini. Sejarah Pendidikan Islam. Bandung: Bumi Aksara. 2008. 